\section{A Review of Weed Control Practices in Landscape Planting Beds: Part II-Chemical Weed Control Methods}

\author{
S. Christopher Marble ${ }^{1}$ \\ Department of Environmental Horticulture, CLCE, IFAS, University of \\ Florida Mid-Florida Research and Education Center, 2725 South Binion \\ Road, Apopka, FL 32703
}

\section{Andrew K. Koeser and Gitta Hasing}

Department of Environmental Horticulture, CLCE, IFAS, University of Florida Gulf Coast Research and Education Center, 14625 County Road 672, Wimauma, FL 33598

Additional index words. herbicides, homeowner, horticulture, landscape, preemergent, postemergent, ornamental

\begin{abstract}
Use of preemergence and postemergence herbicides is the most effective and economical method of weed control in landscape planting beds. When used correctly, herbicides can provide satisfactory weed control, reduce labor costs, and cause little or no negative environmental impacts. Major factors in herbicide efficacy include choosing the correct herbicide for the weed species present, following proper calibration procedures, and applying herbicides at the correct timing. The objective of this review is to provide a comprehensive analysis of the research pertaining to herbicide use in landscape planting beds and present 1 ) the advantages and disadvantages of common chemical weed control strategies, 2) the most effective preemergence and postemergence herbicides in various landscape scenarios, 3) potential environmental concerns pertaining to improper application of herbicides, and 4) highlight knowledge gaps where additional research is needed or improvements could be made.
\end{abstract}

Since 2,4-D was discovered in the 1940s, development and use of herbicides has continually increased (Timmons, 2005). Use of herbicides in residential landscapes is also increasing. From 1994 to 2007, there has been a $60 \%$ increase in sales of pesticides to the home and garden market sector with herbicides being the most purchased pesticide (EPA, 2011). Pesticides for nonstructural pests have been applied on residential landscapes of $\approx 50 \%$ of all U.S. households and the annual expenditure for pesticides in the home and landscape is continually increasing (EPA, 2011; Templeton et al., 1998). The primary motivation for controlling weeds is for aesthetic purposes and so people can more fully enjoy their landscapes for recreational activities (Beard and Green, 1994). Wellmaintained landscapes also have been shown to increase property values (Henry, 1994).

Chemical weed control in landscape planting beds presents unique challenges not present in cropping systems. First, herbicides that are used in landscapes are applied primarily for

Received for publication 7 Jan. 2015. Accepted for publication 11 Mar. 2015.

We thank the University of Florida Center for Landscape Conservation and Ecology for financial support. ${ }^{1}$ To whom reprint requests should be addressed; e-mail marblesc@ufl.edu. in which further research and improvements are needed or where current practices could potentially be improved.

\section{Chemical Weed Control}

Current challenges. Few chemical options exist for weed control around or over-the-top of ornamentals, and the diversity of species in any one landscape planting bed makes finding safe and effective herbicides very difficult for landscapers. Homeowners may face greater challenges with weed control, as many lack the credentials and training required to obtain and safely use the most effective herbicides. However, there are several preemergence and postemergence herbicides labeled for use in and around ornamental plantings in residential landscapes. Many of the herbicides available for use in residential landscapes are available for both professional and homeowner use. However, products intended to be used by nonlicensed homeowners are typically granular, less concentrated formulations or packaged as more expensive, ready-to-use products It is likely that very few new herbicide active ingredients are on the horizon specifically for the ornamental or landscape market (Fennimore and Doohan, 2008). Therefore, more data are needed on herbicides labeled in other markets for their suitability for use in landscape ornamentals, as well as determining the most effective and efficient ways in which current products can be used.

Preemergence weed control. Landscape professionals (and some homeowners) commonly make preemergence herbicide applications to landscape beds followed by postemergence applications to control escaped weeds. Many preemergence herbicides can offer some control of both grass and broadleaf weeds, but most are more effective or are primarily used to control one subclass or the other. Consequently, tank mixtures or combination products are commonly used. Preemergence tank mixtures of primarily broadleaf (e.g., isoxaben, oxadiazon, dichlobenil, and dimethenamid-p) and grass (e.g., oryzalin, pendimethalin, prodiamine, and trifluralin) herbicides or commonly sold combination granular products (e.g., isoxaben + trifluralin, oryzalin + benefin, and dimethenamid-p + pendimethalin) will generally offer broadspectrum control and reduce the number of applications that must be made (Gallitano and Skroch, 1993; Gilliam et al., 1989; Monaco and Hodges, 1974). Tank mixes can also be more cost-effective than the components applied alone. In a study by Wehtje et al. (2010), a flumioxazin and prodiamine tank mixture was most cost-effective for control of spotted spurge (Chamaesyce maculata) and large crabgrass (Digitaria sanguinalis); however, prodiamine was shown to be antagonistic in this tank mixture for control of eclipta (Eclipta alba). Determining synergism or antagonism of other common landscape herbicide tank mixtures for weed control is much-needed information for assessing economically viable tank mixtures for the landscape industry. 
A small subgroup of preemergence herbicides also offers control of perennial sedge species (Cyperus spp.) (Keeley and Thullen, 1974). The most common perennial sedge species, yellow (Cyperus esculentus) and purple nutsedge (Cyperus rotundus), are often the most difficult weeds to control preemergence due their ability to reproduce by underground tubers, which are long lived and difficult to kill while dormant (Bryson et al., 2003; Thullen and Keeley, 1979; Wills, 1987). Herbicides labeled for preemergence control of nutsedge species include dimethenamid-p (Tower ${ }^{\circledR}$, and as a component in FreeHand ${ }^{\circledR}$; BASF Corporation, Research Triangle Park, NC), S-metolachlor (Pennant Magnum ${ }^{\circledR}$; Syngenta Crop Protection, Inc., Greensboro, NC), S-ethyl dipropylthiocarbamate or EPTC (Etpam ${ }^{\circledR}$; Gowan USA Turf and Ornamental Co., Yuma, AZ), and dichlobenil (Casoron ${ }^{\circledR}$; OHP, Inc., Mainland, PA) (Vencill, 2002). All of these products differ in their efficacy and ornamental safety profile. In most cases, metolachlor is the most effective preemergence herbicide for control of yellow nutsedge (Altland et al., 2003). Both S-metolachor and dimethenamid-p are safe for over-the-top applications to many different ornamental species, but neither product is labeled for control of purple nutsedge. Dichlobenil and EPTC have been shown to provide control of both nutsedge species (Chen et al., 2013; Hardcastle and Wilkinson, 1968; Pereira et al., 1987) but dichlobenil is only labeled for nutsedge control in noncrop areas and both products have a limited list of labeled ornamentals. Currently, there is not a wealth of information available on how these different preemergence nutsedge herbicides interact with other factors in landscape plantings. More research is be needed on different nutsedge preemergence products used in combination with other control factors (i.e., mulch) in landscape settings, similar to the study conducted by Chen et al. (2013).

Several active ingredients have been labeled for use in landscapes in recent years. Dimethenamid-p (Tower ${ }^{\circledR}$ and FreeHand ${ }^{\circledR}$ ) is labeled for control of grasses, broadleaves, and sedges in landscape beds and warmseason turf. Flumioxazin (SureGuard ${ }^{\circledR}$; Valent U.S.A. Corp., Walnut Creek, CA) was registered for use in landscapes in 2009 and is gaining popularity with landscape managers for its ability to control many different annual broadleaf and grass species both preemergence and postemergence (Jursik et al., 2011; Richardson and Zandstra, 2006). The latest herbicide labeled for use in landscapes is indaziflam (Specticle ${ }^{\circledR}$; Bayer Environmental Science, Research Triangle Park, NC). Indaziflam is registered for use in turf and as a directed spray in landscape ornamentals and provides control of many annual grass and broadleaf weed species (Kaapro and Hall, 2012). All three of these newer products offer an alternative to many of the older preemergence herbicides that have historically been heavily dinitroanaline based, thus reducing the probability of herbicide resistance due to overuse of one mode of action (Mallory-Smith and Retzinger, 2003).
Turf herbicides have been shown to damage nearby ornamentals due to volatility (Busey et al., 2003) and root uptake (Patton et al., 2011). One of the more notorious instances of ornamental damage due to turf application was with the use of aminocyclopyrachlor (formerly sold as Imprelis ${ }^{\circledR}$; Dupont, Willmington, DE), which damaged or killed thousands of trees and shrubs across the United States (Patton et al., 2013). On the other hand, some herbicides safe for broadleaf ornamental species can significantly injure certain turfgrass species (Bhowmik and Bingham, 1990). Therefore, preemergence herbicides that are labeled for use in both landscape planting beds overthe-top of ornamentals and turf sites are a valuable tool for landscape managers. Most commonly used products including isoxaben (Gallery ${ }^{\circledR}$; Dow AgroSciences, Indianapolis, IN), dimethenamid-p $\left(\right.$ Tower $\left.^{\circledR}\right)$, dithiopyr (Dimension ${ }^{\circledR} ; 2 \mathrm{EW}$, Dow Agrosciences), pendimethalin (Pendulum ${ }^{\circledR}$ 3.3EC; BASF Corporation), and prodiamine (Barricade ${ }^{\circledR}$; Syngenta Crop Protection) offer the ability to apply a single product to multiple areas on a given site, which saves time and reduces the need to transport multiple products or recalibrate on site and serves as a safeguard for crop injury in cases of misapplication.

Preemergence herbicide and mulch interactions. In most cases, preemergence herbicide applications are applied to landscape beds that are already mulched, which can impact the effectiveness of some preemergence herbicides. Mulches that are made up of coarse particle materials may be less likely to reduce herbicide efficacy compared with fine particle materials. Some herbicides are bound tightly by organic matter, which minimizes leaching (Knight et al., 2001), but it is still unknown whether this tight adsorption truly reduces herbicide efficacy as noted by Wilen and Elmore (2007). Chen et al. (2013) studied mulch and herbicide interactions by applying EPTC (Eptam 5G; Gowan USA Turf \& Ornamental Co.) at two rates either above or below pine straw, pine nuggets, or shredded cypress mulch compared with a nonmulched control. Results indicated that EPTC provided better yellow nutsedge control when applied under mulch (12 weeks control) in comparison with applications above mulch (4 weeks control). A study in conservation tillage for rice production showed that herbicides oxadiazon and pendimethalin bound tightly with organic rice crop residues when applied on top of the residue mulch, reducing their effectiveness on some weed species (Chauhan and Abugho, 2012). Similar studies in other row crop situations have also shown varying effects of herbicide applications to organic matter on the soil surface, showing both increased (Crutchfield et al., 1985) and decreased (Banks and Robinson, 1986) efficacy depending on the herbicide and mulch material used. Somireddy (2012) evaluated granular and spray formulations of trifluralin and isoxaben in combination with various organic mulches at different depths. Results indicated that these herbicides generally persisted longer and provided better weed control when applied underneath mulch compared with when herbicides where applied alone (without mulch) or on top of mulch, but results varied depending on formulation (liquid vs. granular) and mulch type. Almost complete weed control was achieved in the thickest mulch treatment $(12 \mathrm{~cm} ; 4.8$ inches) regardless if herbicides were included or not, and herbicides were needed to achieve acceptable control at lower mulch levels $(3 \mathrm{~cm} ; 1$ inch).

Currently, there are no "herbicide placement" recommendations on preemergence herbicide labels in terms of above or below mulch layers. There is a knowledge gap in this area and further research is needed on different mulch and herbicide combinations so that herbicide recommendations for different mulch materials can be developed. Specific questions that need to be answered include which herbicide active ingredients and formulations are most effective for different types of mulches, how particle size of different mulch materials impacts herbicide efficacy, and how irrigation practices should be managed for different mulch types. For example, most herbicides require at least 0.6 to $1.3 \mathrm{~cm}(0.25$ to $0.5 \mathrm{inch})$ of irrigation after application for activation, but more irrigation may be needed when using certain formulations on different mulch types at varying depths to move the herbicide through the mulch layer to reach the soil below. It is also important to focus future efforts on identifying effective herbicides that can be applied on top of mulch, as there are limited opportunities to apply herbicides below mulch in landscape situations. As noted by Somireddy (2012), the physiochemical properties of every herbicide and mulch are unique, and the adsorption-desorption relationship between different herbicide mulch combinations will vary and influence how well herbicides are released into the soil, which will ultimately influence efficacy.

Failure of preemergence herbicides. Precise, timely applications of herbicides have been shown to be one of the most effective weed control measures in the landscape, but these herbicides can fail for one or more reasons. As stated by Altland et al. (2003), the primary reasons herbicides fail include 1) improper application timing, 2) improper application rate (not being correctly calibrated), and 3) not choosing the most effective herbicide for the most prevalent weed species. Preemergence herbicides are not likely to provide season-long control, and most provide control for only 10 to 14 weeks (Wehtje and Gilliam, 1991). In an intensive production system, such as container production, preemergence herbicides may only provide control for 4 to 6 weeks (Atwood et al., 2008; Judge et al., 2003). Therefore, follow-up applications are needed before the herbicide degrades. Previous research has shown that timing of preemergence applications is often more important than herbicide selection (Wehtje and Gilliam, 1991). These 
applications should also be made to weedfree areas for the best control; however, several commonly used preemergence herbicides have been shown to provide early postemergence activity. Studies by Altland et al. (2000) show that small hairy bittercress (Cardamine hirsuta) $(0.5$ to $3 \mathrm{~cm})$ can be controlled with applications of isoxaben. Spotted spurge has been successfully controlled in the cotyledon to one-leaf stage of growth with applications of herbicides including dimethenamid-p + pendimethalin, pendimethalin, and dimethenamid-p (Marble et al., 2011). An earlier study by Judge and Neal (2006) showed hairy bittercress and spotted spurge (C. maculata) can be controlled successfully with the herbicides flumioxazin, oxyfluorfen + pendimethalin, and isoxaben + trifluralin at the cotyledon to oneleaf stage of growth. The new herbicide indaziflam provides effective preemergence control of grass and broadleaf weeds (Marble et al., 2013; Myers et al., 2009) and has been shown to provide early postemergence control of common weeds in turfgrass and landscapes (Brosnan et al., 2011, 2012; Marble et al., 2013). Similarly, dithiopyr (Dimension ${ }^{\circledR}$ ) is labeled to control crabgrass (Digitaria spp.) plants that have five leaves or less (Dow AgroSciences, 2010). With the exceptions of the liquid formulations of indaziflam and flumioxazin, all of these active ingredients have broad over-the-top labels for a wide variety of landscape ornamentals, which give landscapers the advantage of controlling certain small weeds when making preemergence applications. The liquid formulations of flumioxazin and indaziflam could also provide this benefit when used as a directed-spray application. Although earlier work offers some promising insights into new herbicide strategies, all of these studies were conducted on common weed species in container nurseries. More work is needed to determine if these preemergence herbicides can provide early postemergence control of weed species common in landscape plantings and to determine how a landscape setting impacts efficacy.

Postemergence weed control. Postemergence herbicides labeled for use in landscapes include nonselective herbicides such as the translocated glyphosate (RoundUp ${ }^{\circledR}$; Monsanto Co., St. Louis, MO), or contact herbicides such as diquat (Reward ${ }^{\circledR}$; Syngenta Crop Protection) or pelargonic acid (Scythe ${ }^{\circledR}$; Gowan Co.). Glufosinate (Finale ${ }^{\circledR}$; Bayer Environmental Sciences) is another nonselective herbicide that is minimally translocated (Mersey et al., 1990) and thus acts more as a contact herbicide. Graminicides such as clethodim $\left(\right.$ Envoy $^{\circledR}$; Valent USA Corp.), fluazifop-P-butyl (Fusilade ${ }^{\circledR}$; Syngenta Crop Protection), fenoxaprop-p-ethyl (Acclaim $^{\circledR}$; Bayer Environmental Sciences), or sethoxydim (Segment ${ }^{\circledR}$; BASF Corporation) are also widely used because they provide selective control of grass species and are safe for over-the-top application to a wide variety of broadleaf ornamentals.

With the exception of graminicides, postemergence weed control in landscape beds primarily involves making directed or spot applications to avoid damage to nearby ornamentals. The most commonly used postemergence herbicide in landscape beds is glyphosate, which is economical, has little human or nontarget toxicity (other than to nontarget plants), and is immobile in soil (NPIC, 2014). As glyphosate is nonselective and will control most weed species, its use eliminates much of "guess work" by homeowners or inexperienced applicators - it can be used as a stand-alone tool (in the absence of glyphosate resistant weeds). However, landscape ornamentals will usually recover faster following an inadvertent application with a contact herbicide (i.e., diquat) as opposed to a systemic herbicide (i.e., glyphosate) as minimal translocation will occur. Although glyphosate offers advantages, many ornamental species will not recover if exposed to even a small amount of glyphosate (Hoogmoed et al., 2009). On the other hand, it should be noted that many commonly grown ornamental species have shown tolerance to over-the-top applications of glyphosate at low rates including lily turf (Liriope muscari), several holly (Ilex spp.) species, nandina (Nandina domestica), dwarf gardenia (Gardenia jasminoides 'Radicans'), juniper (Juniperus conferta 'Blue Pacific'), Asiatic jasmine (Trachelospermum asiaticum), and camellia (Camellia sasanqua 'Shishigashira') (Hoogmoed et al., 2009; Hoogmoed et al., 2013; Self, 1974; Self and Washington, 1977).

Selective nutsedge herbicides have been developed in the last several decades (Pereira et al., 1987). Halosulfuron (SedgeHammer ${ }^{\circledR}$; Gowan Co.), imazaquin (Image ${ }^{\circledR}$; BASF Corporation), bentazon (Basagran ${ }^{\circledR} \mathrm{T} / \mathrm{O}$; BASF Corporation), and sulfosulfuron (Certainty ${ }^{\circledR}$, Monsanto Co.) are selective nutsedge herbicides that can be applied in turf areas and in and around landscape ornamentals. Similar to preemergence nutsedge herbicides, these products differ in their efficacy and safety to ornamentals. Imazaquin and halosulfuron are labeled for control of both purple and yellow nutsedge, although some reports suggest halosulfuron may be more effective (Blum et al., 2000). In contrast to halosufluron that is labeled only for directed applications, imazaquin can be applied over the top of a small number of ornamental species, including common groundcovers such as Asiatic jasmine, mondo grass (Ophiopogon japonicas), and liriope (Liriope muscari 'Evergreen giant' and 'Silvery sunproof') in addition to several other perennials, shrubs, and trees. Bentazon is only labeled for control of yellow nutsedge (and some broadleaf species) but can be applied as a directed spray around almost all ornamental species and applied over the top to more than 20 species of shrubs, trees, and perennials. In a study by Johnson (1975), bentazon provided $98 \%$ to $100 \%$ control of purple nutsedge following a spring application, but control decreased to $28 \%$ to $68 \%$ following mid or late summer application, indicating that bentazon could provide some control of both yellow, and possibly purple nutsedge, depending on application timing and weed growth stage. Sulfosulfuron was originally a turf-only herbicide but now has a supplemental landscape ornamental label. Sulfosulfuron is labeled for the control of both purple and yellow nutsedge and can be applied over the top of over 20 woody ornamentals, eight warm-season native grasses, and as a directed application to any established warm-season ornamental grass or ornamental species in landscaped areas (Monsanto Co., 2012).

Current industry trends. One of the primary downsides to glyphosate use in the landscape is that depending on weed species and stage of growth, symptoms may not be noticeable for $7 \mathrm{~d}$ or more after application (Franz et al., 1997; Monsanto Co., 2010), which is unacceptable by some homeowners who want immediate confirmation that the product is working. As a result, numerous ready-to-use products are marketed that have glyphosate as their main component but also contain a faster-acting herbicide such as diquat or pelargonic acid (Wehtje et al., 2008, 2009). These products do in fact cause faster burn down, but in some cases may not allow glyphosate to fully translocate throughout the weed, and better long-term control may be achieved by using glyphosate alone. When tank mixtures of glyphosate and diquat were evaluated for control of longstalk phyllanthus (Phyllanthus tenellus), a summer annual weed (or perennial in subtropical environments), the amount of glyphosate had to be increased by $\approx 60 \%$ to compensate for diquatbased antagonism (Wehtje et al., 2008). In a similar study, Wehtje et al., (2009) concluded that the addition of pelargonic acid to glyphosate neither increased nor decreased long-term control of four common annual weed species (large crabgrass, yellow nutsedge, long-stalked phyllanthus, and prostrate spurge). Similarly, antagonism has also been reported with glufosinate + glyphosate combinations (Chuah et al., 2008). Based on these trials, it appears that in most cases, a more economical and effective approach would be to apply glyphosate alone. In cases where faster burn down was desired, applying fast-acting contact herbicides alone could suit this purpose, but many of these products are not available to homeowners in concentrate form, and most products are more expensive than glyphosate. Applying tank mixes or contact + systemic products correctly may be useful if allowed on the label or sold premixed, but it is important to note that the most effective control may be achieved when using glyphosate alone. As antagonism of glyphosate + contact tank mixtures has been reported with annual species (Wehtje et al., 2008), it would likely be more pronounced in the case of some perennial species.

\section{Environmental Impacts of Herbicide Use and Public Perceptions}

Using the correct herbicide at the appropriate rate is a critical step in weed management (Altland et al., 2004). Chemical costs, 
the likelihood of unintended phytotoxicity (Stamps and Neal, 1990), and pollution (Frick et al., 1998) can increase when too much herbicide is applied. In contrast, suboptimal application rates lead to poor weed control (Altland et al., 2004) and herbicide resistance development (Busi and Powles, 2009). Selecting the right product and applying the correct rate may be a challenge for homeowners who have not had training. In a study by North Carolina extension educators, the most often requested information by homeowners was how to select the correct product, how to understand pesticide labels, and how to know the proper amount to apply (Church et al., 2012). These three skills are critical for safe and effective herbicide application. In their work, Church et al. (2012) concluded that most homeowners do not have a complete understanding of the risks associated with pesticide use. The potential for widespread misuse is significant as the EPA estimates that 41 million households use herbicides (EPA, 2011). Sales of herbicides to the home and garden market increased from \$456 million in 1994 to \$749 million in 2007 (EPA, 2011). As herbicide use continues to increase, it is important to educate all applicators on correct usage, handling, storage, and disposal of these products to prevent point and nonpoint source pollution.

Numerous studies have pointed to the possibility of negative consequences from herbicide applications including exposure risks to people (Greenlee et al., 2004; Nishioka, et al., 2001), pets (Glickman, et al., 2004), nontarget organisms (Dewey, 1986), and water contamination (Frick et al., 1998; USGS, 1999). Herbicide runoff in urban areas can exceed that of agricultural areas due to frequent use and lack of consumer awareness (Wittmer et al., 2011). Some herbicides (and metabolites) commonly found in surface and groundwater can persist for decades and many are toxic to aquatic organisms and have adverse effects on human health (Jablonowski et al., 2011; Ochoa-Acuna et al., 2009). The top five most commonly used herbicide active ingredients in the home and garden market sector in 2007 included 2,4-D, glyphosate, mecoprop (MCPP), pendimethalin, and dicamba, in order of use (EPA, 2011). Not surprisingly, 2,4-D has been one of the most frequently detected herbicides in urban water sources (USGS, 1999). 2,4-D is a selective broadleaf herbicide and is commonly used for weed control in turf and often sold in combinations with MCPP and dicamba in popular "weed and feed" products, which contain various herbicide + fertilizer combinations for use in turf areas. Mecoprop is also a common ingredient in widely used weed-and-feed products. Although all of the top five sold herbicide active ingredients have labels for both turf and landscape bed applications, with the exception of glyphosate and pendimethalin, these products are almost exclusively applied to turf areas. In addition, applications to turf areas will naturally be more frequent and require more product because of their larger area compared with ornamental beds in most landscapes. Most landscapes are composed largely of turf areas and homeowners may be required by local ordinance or homeowner association code to dedicate a portion of their landscape to turf (Schindler, 2014). In some cases, these sites can be poor areas for turfgrass establishment due to environmental or cultural factors. Removing turf requirements in these sites and allowing the use of alternative groundcovers, native plants, or landscape beds may help reduce the need for frequent pesticide applications and mitigate water contamination. However, overcoming informal norms, customs, and personal preferences may be more of a challenge than eliminating formal regulations or local codes (Larson and Brumand, 2014).

\section{Assessing the Potential for Organic Landscaping and Herbicide Use}

When used according to their labels, pesticides in general pose little threat for humans, animals, nontarget organisms, and the environment (Holland, 2012), but consumers are often still wary of their use and many now prefer organic or "natural" products. Consumers are becoming more willing to pay premium prices for organic foods (Batte et al., 2007), mostly because organic agriculture is thought to be less damaging to the environment, healthier for consumption (Williams and Hammit, 2001), and there are fewer perceived risks associated with consuming organically produced foods (Saba and Messina, 2003). Research has also shown that consumers often prefer environmentally friendly products (Yue et al., 2010) that were produced sustainably (Yue et al., 2009); however, a demand for organically produced ornamental plant materials has not yet been readily evident (Yue et al., 2011).

Organically produced ornamentals are currently not in high demand, likely because they are not consumed. However, there is a possibility that organically maintained landscapes could become more popular because many feel pesticides are "harmful" when being applied in close proximity to public buildings, schools, and homes (Arya, 2005). Many provinces in Canada began banning or highly restricting the use of nonessential or "cosmetic" pesticides in the 1990s and 2000s (Sandberg and Foster, 2005). Although these bans were highly debated and resulted in some negative consequences, such as public parks being unusable due to weed pressure (Holland, 2012), concentrations of herbicides in urban streams have significantly decreased in areas where bans were passed (Todd and Struger, 2014). Results from a survey of landscaping firms in Long Island, NY, indicate that there has recently been a wide adoption of organic landscaping practices, and that many of these companies are experiencing stable, albeit slow growth (Haas et al., 2013). These businesses generally cater to niche, often high-income markets and have clients that are very environmentally conscious, or otherwise have an aversion to chemical use on their landscape (i.e., chemical sensitivities, etc.). Because of these concerns, interest has increased in recent years pertaining to use of "natural" herbicides such as acetic acid (vinegar) and other products such as citric acid, d-limonene and clove, cinnamon, and lemongrass oil (Daniels and Fults, 2002; Evans and Bellinder, 2009; Lanini, 2012). These products are also often perceived to be safer for the applicator in comparison with synthetic herbicides; however, that is not necessarily the case. For example, acetic acid concentrations over $10 \%$ (the concentration generally needed for effective weed control) can cause severe burns and irreversible eye damage (Coban, 2007; Daniels and Fults, 2002). The majority of these herbicides work by contact, have no selective activity, and are not translocated throughout the weed, typically only controlling small annual species (Daniels and Fults, 2002; Lanini, 2012). In a study by Ferguson (2004), citric acid, clove oil, and thyme/clove oil were compared with glyphosate for control of common broadleaf and grass weeds. In this trial, organic herbicides provided $10 \%$ to $40 \%$ weed control compared with $100 \%$ control with glyphosate. A Minnesota survey reported that a typical homeowner tolerates up to $10 \%$ weeds in their lawns (Carpenter and Meyer, 1999), but customers who use organic landscaping services or herbicides may have to tolerate more than $10 \%$ weeds, and in some cases may still pay higher fees compared with conventional maintenance costs. However, if this type of service was known to have a wide appeal, landscape companies could begin to offer organic services, or new businesses could be developed and market themselves as organic as a way to differentiate themselves in a competitive marketplace. Many of these companies lack the resources needed to conduct a thorough market analysis, and currently there is a need to determine if organic landscaping maintenance would be a sustainable business model, and identify geographical areas in which these businesses could operate successfully.

\section{Conclusion}

Many different herbicides are available for providing weed control in landscape planting beds. However, no one herbicide will control all the weeds, and the best success will most likely be achieved by using a variety of chemical and nonchemical methods using an integrated approach. A review of the literature pertaining to weed control in landscapes reveals several knowledge gaps that offer potential for future progress. Compared with agronomic or food crops, weed control research, specifically herbicide safety and efficacy testing, in specialty crops receives little funding for research (Fennimore and Doohan, 2008), and weed control in landscapes is often an afterthought. However, determining new weed control methods in landscape plantings and improving on current practices could 
potentially provide significant benefits including improved profit margins for landscapers, increased property values, and also help to mitigate negative environmental impacts from over application of herbicides in urban and suburban areas. Future research should be focused on determining the best integrated weed control practices and how different methods can be combined to improve weed control and reduce costs. Specific areas in which progress could be made include determining the best mulch + herbicide combinations, testing more herbicides for crop tolerance on additional ornamental species, and evaluating synergism and antagonism of common herbicide tank mixes for landscape applications. Continual training and education are needed not only for professional applicators but also for homeowners applying pesticides.

\section{Literature Cited}

Altland, J.E., C.H. Gilliam, J.H. Edwards, G.J. Keever, J.R. Kessler, and D.J. Eakes. 2000. Effect of bittercress size and gallery rate on postemergence bittercress control. J. Environ. Hort. 18:128-132.

Altland, J.E., C.H. Gilliam, and G.W. Wehtje. 2003. Weed control in field nurseries. HortTechnology 13:9-14.

Altland, J.E., G.B. Fain, and K. Von Arx. 2004. Fertilizer placement and herbicide rate affect weed control and crop growth in containers. J. Environ. Hort. 22:93-99.

Arya, N. 2005. Pesticides and human health: Why public health officials should support a ban on non-essential residential use. Can. J. Public Health 96:89-92.

Atwood, R.P.M., L.C. Walker, and J.C. Neal. 2008. Longevity of weed control in containers with BAS659H. Proc. Northeastern Weed Sci. Soc. 62:26.

Banks, P.A. and E.L. Robinson. 1986. Soil reception and activity of acetachlor, alachlor, and metolachlor as affected by wheat (Triticum aestivum) straw and irrigation. Weed Sci. 34:607-611.

Batte, M.T., N.H. Hooker, T.C. Haab, and J.B. Beaverson. 2007. Putting their money where their mouths are: Consumer willingness to pay for multi-ingredient, processed organic food products. Food Policy 32:145-159.

Beard, J.B. and R.L. Green. 1994. The role of turfgrasses in environmental protection and their benefits to humans. J. Environ. Qual. 23:452-460.

Blum, R.R., J. Isgrigg, III, and F.H. Yelverton. 2000. Purple (Cyperus rotundus) and yellow nutsedge (Cyperus esculentus) control in bermudagrass (Cynodon dactylon) turf. Weed Technol. 14:357-365.

Bhowmik, P.C. and S.W. Bingham. 1990. Preemergence activity of dinitroaniline herbicides used for weed control in cool-season turfgrasses. Weed Technol. 4:387-393.

Brosnan, J.T., G.K. Breeden, P.E. McCullough, and G.M. Henry. 2012. PRE and POST control of annual bluegrass (Poa anna) with indaziflam. Weed Technol. 26:48-53.

Brosnan, J.T., P.E. McCullough, and G.K. Breeden. 2011. Smooth crabgrass control with indaziflam at various spring timings. Weed Technol. 25:363-366.

Bryson, C.T., K.N. Reddy, and W.T. Molin. 2003. Purple nutsedge (Cyperus rotundus) Population dynamics in narrow row transgenic cotton (Gossypium hirsutum) and Soybean (Clycine max) rotation. Weed Technol. 17:805-810.

Busey, P., T.K. Broschat, and D.L. Johnston. 2003. Injury to landscape and vegetable plants by volatile turf herbicides. HortTechnology 13:650-653.

Busi, R. and S.B. Powles. 2009. Evolution of glyphosate resistance in a Lolium rigidum population by glyphosate selection at sublethal doses. Heredity 103:318-325.

Carpenter, P.J. and M.H. Meyer. 1999. Edina goes green Part III: A survey of consumer lawn care knowledge and practices. HortTechnology 9:491-494.

Chauhan, B.S. and S.B. Abugho. 2012. Interaction of rice residue and pre herbicides on emergence and biomass of four weed species. Weed Technol. 26:627-632.

Chen, Y., R.E. Strahan, and R.P. Bracy. 2013. Effects of mulching and preemergence herbicide placement on yellow nutsedge control and ornamental plant quality in landscape beds. HortTechnology 23:651-658.

Christians, N. 1998. Fundamentals of turfgrass management. Ann Arbor Press, Chelsea, MI.

Church, C.S., W.G. Buhler, L.K. Bradley, and R.E. Stinner. 2012. Assessing extension educator's needs for homeowner pesticide use and safety information. J. Ext. Article 5RIB7. 24 Dec. 2014. <http:/ www.joe.org/joe/2012october/rb7.php\#top>.

Chuah, T.S., H.H. Tehs, T.S. Cha, and B.S. Ismail. 2008. Antagonism of glufosinate ammonium activity caused by glyphosate in the tank mixture used for control of goosegrass (Eleusine indica Gaertn.). Plant Prot. Q. 23:116-119.

Coban, Y.K. 2007. Superficial burns secondary to misuse of acetic acid solution. J. Burn Care Res. 28:359-360.

Crutchfield, D.A., G.A. Wicks, and O.C. Burnside 1985. Effect of winter wheat (Triticum aestivum) straw mulch level on weed control. Weed Sci. 34:110-114.

Daniels, C.H. and J. Fults. 2002. Fact sheet for vinegar/acetic acid recommendations. Oregon Department of Agriculture Factsheet No. PIC01002, Salem, OR.

Dewey, S.L. 1986. Effects of the herbicide atrazine on aquatic insect community structure and emergence. Ecology 67:148-162.

Dow AgroSciences. 2010. Dimension ${ }^{\circledR}$ herbicide product label, p. 16. Dow AgroSciences, Indianapolis, IN.

EPA. 2011. Pesticide industry sales and usage: 2006 and 2007 market estimates. EPA 733-R$11-001$.

Evans, G.J. and R.R. Bellinder. 2009. The potential use of vinegar and a clove oil herbicide for weed control in sweet corn, potato, and onion. Weed Technol. 23:120-128.

Fennimore, S.A. and D.J. Doohan. 2008. The challenges of specialty crop weed control, future directions. Weed Technol. 22:364-372.

Ferguson, J. 2004. Evaluation of organic herbicides. HortScience 4:876 (abstr.)

Franz, J.E., M.K. Mao, and J.A. Sikorski. 1997. Glyphosate: A unique global herbicide. American Chemical Society, Washington, DC.

Frick, E.A., D.J. Hippe, G.R. Buell, C.A. Couch, E.H. Hopkins, D.J. Wangsness, and J.W. Garrett. 1998. Water quality in the ApalachicolaChattahoochee-Flint River Basin-Georgia, Alabama, and Florida: 1992-1995. U.S. Geol. Surv. Circ. 1164. U.S. Geol. Survey, Denver, CO.

Gallitano, L.B. and W.A. Skroch. 1993. Herbicide efficacy for production of container ornamentals. Weed Technol. 7:103-111.
Gilliam, C.H., G. Wehtje, J.E. Eason, T.V. Hicks, and D.C. Fare. 1989. Weed control with Gallery and other herbicides in field-grown nursery crops. J. Environ. Hort. 7:69-72.

Glickman, L.T., M. Raghavan, D.W. Knapp, P.L. Bonney, and M.H. Dawson. 2004. Herbicide exposure and the risk of transitional cell carcinoma of the urinary bladder in Scottish terriers. J. Amer. Vet. Med. Assoc. 224:1290-1297.

Greenlee, A.R., T.M. Ellis, and R.L. Berg. 2004. Low-dose agrichemicals and lawn-care pesticides induce developmental toxicity in murine preimplantation embryos. Environ. Health Perspect. 112:703-709.

Haas, J., A. Manitt, and D. Maratos. 2013. Organic landscaping is sustainable business. A report by the Neighborhood Network Research Center, Inc. on the State of Long Island's Organic Landscaping. 24 Dec. 2014. < http://neighborhoodnetwork. org/pesticides/Organic_is_Sustainable_Business. pdf $>$.

Hardcastle, W.S. and E.E. Wilkinson. 1968. Response of purple and yellow nutsedge to dichlobenil. Weeds 16:339-340.

Henry, M.S. 1994. The contribution of landscaping to the price of single family houses: A study of home sales in Greenville, South Carolina. J. Environ. Hort. 12:65-70.

Holland, J.J. 2012. "Cosmetic" pesticides: Safe to use by professionals and homeowners. J. Entomol. Soc. B.C. 109:3-5.

Hoogmoed, A.V., C.H. Gilliam, G.R. Wehtje, and J.W. Olive. 2009. Can roundup be safely used over-the-top of nursery crops? Proc. South. Nurs. Res. Conf 54:139-142.

Hoogmoed, A.V., C.H. Gilliam, G.R. Wehtje, P.R. Knight, W.G. Foshee, J.W. Olive, and A.M. Murphy. 2013. Effects of repeated applications of Roundup Pro ${ }^{\circledR}$ over the top of container-grown nursery crops. J. Environ. Hort. 31:234-240.

Jablonowski, N.D., A. Schaffer, and P. Burauel. 2011. Still present after all these years: Persistence plus potential toxicity raise questions about the use of atrazine. Environ. Sci. Pollut. Res. 18:328-331.

Johnson, B.J. 1975. Purple nutsedge control with bentazon and perfluidone in turfgrass. Weed Sci. 23:349-353.

Judge, C.A., J.C. Neal, and R.B. Leidy. 2003. Trifluralin (Preen) dissipation from the surface layer of a soilless plant growth substrate. J. Environ. Hort. 21:216-222.

Judge, C.A. and J.C. Neal. 2006. Preemergence and early postemergence control of selected container nursery weeds with Broadstar, $\mathrm{OH} 2$, and Snapshot TG. J. Environ. Hort. 24:105-108.

Jursik, M., J. Andr, J. Holec, and J. Soukup. 2011. Efficacy and selectivity of post-emergent application of flumioxazin and oxyfluorfen in sunflower. Plant Soil Environ. 57:532-539.

Kaapro, J. and J. Hall. 2012. Indaziflam: A new herbicide for pre-emergent control of weeds in turf, forestry, industrial vegetation and ornamentals. Pak. J. Weed Sci. Res. 18:270-367.

Keeley, P.E. and R.J. Thullen. 1974. Yellow nutsedge control with soil-incorporated herbicides. Weed Sci. 22:378-383.

Knight, P.R., C.H. Gilliam, S.L. File, and D. Reynolds. 2001. Mulches reduce herbicide loss in the landscape. Proc. South. Nurs. Assn. Res. Conf. 46:461-463.

Koterba, M.T., C.A. Dieter, and C.V. Miller. 2010. Pesticides in groundwater in the Anacostia River and Rock Creek watersheds in Washingon, D.C., 2005-2008. U.S. Geological Survey Scientific Investigations Report 2010-5130.

Larson, K.L. and J. Brumand. 2014. Paradoxes in landscape management and water conservation: 
Examining neighborhood norms and institutional forces. Cities and the Eviron. 7:6.

Lanini, W.T. 2012. Organic herbicides: Do they work? University of California Davis, UCNFA News. 30 Dec. 2014. <http://ucanr.edu/sites/UCNFAnews/feature_stories/organic_herbicides_-_do_ they_work/>.

Mallory-Smith, C.A. and E.J. Retzinger, Jr. 2003. Revised classification of herbicides by site of action for weed resistance management strategies. Weed Technol. 17:605-619.

Marble, S.C., C.H. Gilliam, G.R. Wehtje, A.J. Van Hoogmoed, and C. Palmer. 2011. Early postemergence control of spotted spurge in container production. J. Environ. Hort. 29:29-34.

Marble, S.C., C.H. Gilliam, G.R. Wehtje, and M. Samuel-Foo. 2013. Early postemergence control of yellow woodsorrel (Oxalis stricta) with residual herbicides. Weed Technol. 27:347-351.

McCarthy, L.B. and T.R. Murphy. 1994. Control of turfgrass weeds, p. 209-248. In: Turgeon, A.J., D.M. Kral, and M.K. Viney (eds.). Turf weeds and their control. ASA and CSSA, Madison, WI.

Mersey, B.G., J.C. Hall, D.M. Anderson, and C.J. Swanton. 1990. Factors affecting the herbicidal activity of glufosinate ammonium: Absorption, translocation, and metabolism in barley and green foxtail. Pestic. Biochem. Physiol. 37:90-98.

Monaco, T.J. and L. Hodges. 1974. Herbicide activity in container-grown ornamentals. Proc. Southern Weed Sci. Soc. 27:186-192.

Monsanto Co. 2010. RoundUp Pro herbicide product label, p. 22. Monsanto Co., St. Louis, MO.

Monsanto Co. 2012. Certainty herbicide product label, p. 5. Monsanto Co., St. Louis, MO.

Myers, D.F., R. Hanrahan, J. Michel, B. Monke, L. Mudge, C. Olsen, A. Parker, J. Smith, and D. Spak. 2009. Indaziflam/BCS AA170717: A new herbicide for preemergent control of grasses and broadleaves in turf and ornamentals. Proc. South. Weed. Sci. Soc. 62:393.

National Pesticide Information Center. 2014. Glyphosate technical fact sheet. 16 Nov. 2014. <http:// npic.orst.edu/factsheets/glyphotech.html $>$.

Nielson, L. and C.L. Smith. 2005. Influences on residential yard care and water quality: Taulatin watershed, Oregon. J. Amer. Water Resour. Assoc. 41:93-106.

Nishioka, M.G., R.G. Lewis, M.C. Brinkman, H.M. Burkholder, C.E. Hines, and J.R. Menkedick. 2001. Distribution of 2,4-D in air and on surfaces inside residences after lawn applications: Comparing exposure estimates from various media for young children. Environ. Health Perspect. 109:1185-1191.
Ochoa-Acuna, H., J. Frankenberger, L. Hahn, and C. Carbajo. 2009. Drinking-water herbicide exposure in Indiana and prevalence of small-for-gestational-age and preterm delivery. Environ. Health Perspect. 117:16191624.

Patton, A., T. Creswell, G. Ruhl, and S. Weller. 2011. A Turf Professionals Guide to Suspected Imprelis Herbicide Injury in the Landscape. Purdue University Plant \& Pest Diagnostic Laboratory publication. 16 Jan. 2013. <http:// www.ppdl.purdue.edu/PPDL/pubs/briefs/ ImprelisLCO.pdf/>.

Patton, A.J., G.E. Ruhl, T.C. Creswell, P. Wan, D.E. Scott, J.D. Becovitz, and D.V. Weisenberger. 2013. Potential damage to sensitive landscape plants from wood chips of aminocyclopyrachlor damaged trees. Weed Technol. 27:803-809.

Pereira, W., G. Crabtree, and R.D. William. 1987. Herbicide action on purple and yellow nutsedge (Cyperus rotundus and C. esculentus). Weed Technol. 1:92-98.

Richardson, R.J. and B.H. Zandstra. 2006. Evaluation of flumioxazin and other herbicide for weed control in gladiolus. Weed Technol. 20:394-398.

Saba, A. and F. Messina. 2003. Attitudes towards organic foods and risk/benefit perception associated with pesticides. Food Qual. Prefer. 14:637-645.

Sandberg, L.A. and J. Foster. 2005. Challenging lawn and order: Environmental discourse and lawn care reform in Cananda. Eviron. Politics 14:478-494.

Self, R.L. 1974. Screening tests with glyphosate on woody ornamentals. Proc. S. Nursery Res. Conf. 19:118-199.

Self, R.L. and O. Washington. 1977. Over-the-top application of Roundup to root cuttings, liners, and pot-grown ornamentals. Proc. S. Nursery Res. Conf. 22:175-176.

Schindler, S. 2014. Banning lawns. George Washington Law Rev. 82:356-394.

Somireddy, U. 2012. Effect of herbicide-organic mulch combinations on weed control and herbicide persistence. Ohio St. Univ. Theses and Diss. 18 Nov. 2014. <https://etd.ohiolink.edu/>.

Stamps, R.H. and C.A. Neal. 1990. Evaluation of dinitroaniline herbicides for weed control in container landscape plant production. J. Environ. Hort. 8:52-57.

Templeton, S.R., D. Zilberman, and S.J. Yoo. 1998. An economic perspective on outdoor residential pesticide use. Environ. Sci. Technol. 32:416-423.

Timmons, F.L. 2005. A history of weed control in the United States and Canada. Weed Sci. 53:748-761.
Thullen, R.J. and P.E. Keeley. 1979. Seed production and germination in Cyperus esculentus and C. rotundus. Weed Sci. 27:502-505.

Todd, A. and J. Struger. 2014. Changes in acid herbicide concentrations in urban streams after a cosmetic pesticide ban. Challenges 5:138151.

Turgeon, A.J. 1996. Turfgrass management. 4th ed. Prentice Hall, Upper Saddle River, NJ.

U.S. Geological Survey. 1999. The quality of our nation's waters: Nutrients and pesticides. U.S. Geological Survey Circ. 1225.

Vencill, W.K. (ed.). 2002. Herbicide handbook. 7 th ed. Weed Science Society of America, Champaign, IL.

Wehtje, G. and C.H. Gilliam. 1991. Weed control in field-grown holly. J. Environ. Hort. 9:2932.

Wehtje, G., J.E. Altland, and C.H. Gilliam. 2008 Interaction of glyphosate and diquat in readyto-use weed control products. Weed Technol. 22:472-476.

Wehtje, G., J.E. Altland, and C.H. Gilliam. 2009 Interaction of glyphosate and pelargonic acid in ready-to-use weed control products. Weed Technol. 23:544-549.

Wehtje, G., C.H. Gilliam, and S.C. Marble. 2010. Interaction of prodiamine and flumioxazin for nursery weed control. Weed Technol. 24:504509.

Wilen, C.A. and C.L. Elmore. 2007. Weed management in landscapes. University of California Agriculture and Natural Resources. Pest Notes Pub. No. 7441.

Williams, P.R.D. and J.K. Hammit. 2001. Perceived risks of conventional and organic produce: Pesticides, pathogens, and natural toxins. Risk Anal. 21:319-330.

Wills, G.D. 1987. Description of purple and yellow nutsedge (Cyperus rotundus and C. esculentus). Weed Technol. 1:2-9.

Wittmer, I., R. Scheidegger, H.S. Bader, H. Singer, and C. Stamm. 2011. Loss rate of urban biocides can exceed those of agricultural pesticides. Sci. Total Environ. 409:920-932.

Yue, C., F. Alrines, and H.H. Jensen. 2009. Discounting spotted apples: Investigating consumers' willingness to accept cosmetic damage in an organic product. J. Agr. Appl. Econ. 14:29-46.

Yue, C., C. Crebitus, M. Bruhn, and H.H. Jensen. 2010. Marketing organic and conventional potatoes in Germany. J. Intl. Food Agribus. Mark. 22:164-178.

Yue, C., J.H. Dennis, B.K. Behe, C.R. Hall, B.L. Campbell, and R.G. Lopez. 2011. Investigating consumer preference for organic, local, or sustainable plants. HortScience 46:610-615. 